\title{
Management and Outcome in Patients with Venous Ulcers of Lower Limbs
} Dr. Bheemaraju Manasa ${ }^{1 *}$, Dr. Shivananda ${ }^{2}$

${ }^{1}$ Final Year Postgraduate, Department of General Surgery, P.E.S. Institute of Medical Sciences and Research, Kuppam, Andhra Pradesh, India

${ }^{2}$ Professor and Head, Department of General Surgery, P.E.S. Institute of Medical Sciences and Research, Kuppam, Andhra Pradesh, India

\author{
DOI: $10.36347 /$ sasjs.2020.v06i01.005 \\ *Corresponding author: Dr. Bheemaraju Manasa \\ Email: manasavarma8487@gmail.com
}

| Received: 04.01.2020 | Accepted: 19.01.2020 | Published: 30.01 .2020

\section{Abstract}

Chronic ulceration of the lower legs is a relatively common condition amongst adults, which causes pain and lead to social distress. Venous ulcers generally affects the older population and most commonly in late 60's. Venous ulceration of the lower limbs is a relatively common condition with symptoms of increasing pain, friable granulation tissue, foul odour, and wound breakdown instead of healing. In the current study a total of 41 study subjects have included who had attended the OPD of department of surgery presenting ulcers of lower limbs at an tertiary care hospital, Kuppam. $79.54 \%$ of the study subjects belong to 31-60 years of age group.75\% were observed to be completely healed and the remaining 17 out of 44 study subjects were not healed. Management of patients with chronic leg ulcers has to be multidimensional and a detailed history, physical examination, necessary investigations, basic and newer treatment modalities should be included and the most important one is to educate the patients on issues of appropriate foot care and the importance of seeking early medical care.

Keywords: Venous ulcer, treatment, healed, medical care.

Copyright @ 2020: This is an open-access article distributed under the terms of the Creative Commons Attribution license which permits unrestricted use, distribution, and reproduction in any medium for non-commercial use (NonCommercial, or CC-BY-NC) provided the original author and source are credited.

\section{INTRODUCTION}

Venous or gravitational ulcers are the most common type of chronic ulcer of leg. Ulcers of leg are a major problem for both the patient and health care providers [1]. These ulcers most commonly affect women twice as frequently as men and they usually identified near the ankle, especially on the medial aspect of the leg. Chronic edema and indurated areas are always present because of an impaired venous return of blood from the lower limb and pigmentation of the lower part of the leg is also common. Varicose veins may or may not be found, so that the term" varicose ulcer" is not appropriate [2].

Venous ulcers are exceedingly common, affecting between $1 \%$ and $2 \%$ of the elderly population [3]. On an average $3.6 \%$ of the people affected were older than 65 years of age [13]. As a wide range of specialties are concerned in their treatment, including surgery, dermatology, geriatrics, and rheumatology, not surprisingly the subsequent results range from good to distressingly poor. The combination of slow or nonexistent healing and frequent recurrence produces unacceptable morbidity and consumes considerable time and health service resources [4]. It was reported that it takes 6 to 12 months on an average for complete healing of ulcer and among them $70 \%$ of them will recur within 5 years of closure [12].

The basic principles of early treatment consists of reduction of edema and increase venous return by a combination of elevation and elastic compression [5]. As leg ulcers are very common, treatment must be available either in the community or in the outpatient department. Treatment requiring special skills or a period of inpatient care is conceivable for only a small proportion of sufferers. They are best treated in a hospital outpatient clinic held regularly for this specific purpose, where nurses trained to apply the appropriate bandages are available.

Venous ulcers cause much disability on account of pain, and they persist indefinitely if not adequately treated. After years of neglect they may become incurable, but usually they respond most satisfactorily to treatment. The aim of this study was to assess the outcome of treatment modalities performed on patients with leg ulcers. 


\section{OBJECTIVES}

- To assess the outcome in patients with venous ulceration after treatment.

- To study the socio-demographic profile affecting the outcome in healing of venous ulcer.

\section{MATERIALS \& METHODS \\ Study Design: Cross- Sectional study}

Study Participants: 44 patients who attended out patient department having venous ulcers during the study period.

Study Period: six months $\left(1^{\text {st } J u n e-30 t h N o v e m b e r ~}\right.$ 2019).

Study Area: Tertiary care hospital, Kuppam.
Inclusion Criteria: All the patients who were attending the outpatient department at the time of data collection.

Exclusion Criteria: Those who are not willing to participate in the study and were having other co morbid conditions.

Ethical Clearance: Ethical clearance was obtained from Institutional Ethical Committee.

Study Instrument: Predesigned, semi structured questionnaire containing the data of the study subjects along with their sociodemographic profile along with their treatment history after explaining the purpose of study.

\section{DATA ANALYSIS}

The collected data was analyzed using SPSS Version 21.0. The interpretation of the results was carried out in the form of percentages and appropriate statistical tests of significance were applied wherever necessary.

\section{RESULTS}

Table-1: Showing age and gender wise distribution of study subjects

\begin{tabular}{|l|l|l|l|}
\hline Age Group & Male (\%) & Female (\%) & Total (\%) \\
\hline$\leq 30$ & $3(10)$ & $1(7.14)$ & $4(9.10)$ \\
\hline $31-60$ & $24(80)$ & $11(78.57)$ & $35(79.54)$ \\
\hline$>60$ & $3(10)$ & $2(14.29)$ & $5(11.36)$ \\
\hline Total & 30 & 14 & 44 \\
\hline
\end{tabular}

Chisquare $=0.242, \mathrm{df}=2, \mathrm{p}$ value $=0.886$

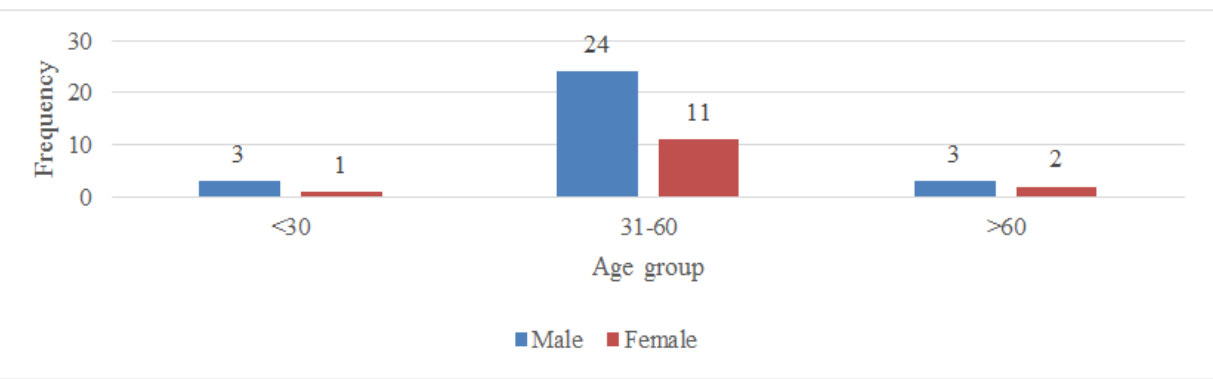

Fig-1: Showing distribution of study subjects with respect to age and gender

From the Table-1 and Figure-1, it is clear that majority I.e., $79.54 \%$ of the study subjects belong to 31 - 60 years of age group and the remaining $20.46 \%$ consists of $\leq 30$ years and $>60$ years age group $(9.1 \%$ and $11.36 \%$ ). And there is no statistically significant association found between age group and gender with a $\mathrm{p}$ value of $>0.05$.

Table-2: Different characteristics observed among the study subjects

\begin{tabular}{|l|l|l|l|}
\hline Characteristics & Frequency & Percentage \\
\hline Occupation & Employed & 35 & 79.54 \\
\cline { 2 - 4 } & Unemployed & 9 & 20.46 \\
\hline \multirow{3}{*}{ Literacy } & Literate & 27 & 61.36 \\
\cline { 2 - 4 } & Illiterate & 17 & 38.64 \\
\hline \multirow{3}{*}{ Pain Involved } & Right & 26 & 59.0 \\
\cline { 2 - 4 } & Left & 12 & 27.27 \\
\cline { 2 - 4 } & Both & 6 & 13.73 \\
\hline & Present & 44 & 100 \\
\cline { 2 - 4 } & Absent & 0 & 0 \\
\hline
\end{tabular}


In Table-2, occupation, literacy, limb involved and pain were studied and it was observed that $79.54 \%$ of the study subjects were earning money through some form of work and only $61.36 \%$ were found to be literate. It was observed that in $59 \%$ of study subjects only right limb was involved, in $27.27 \%$ of them only left limb involvement was seen and in the remaining $13.73 \%$ both the limbs were involved. Pain was observed in all the study subjects studied.

Table-3: Showing various treatment methods applied on the study subjects
\begin{tabular}{|l|l|l|}
\hline Treatment done & Frequency (N) & Percentage (\%) \\
\hline General measures & 1 & 2.27 \\
\hline $\begin{array}{l}\text { General measures and } \\
\text { conservative }\end{array}$ & 20 & 45.45 \\
\hline General measures and surgery & 23 & 52.28 \\
\hline
\end{tabular}

Table-3 gives the details about the treatment method applied on each study subject and in 52.28\% of the study subjects General management and surgery was done, in $45.45 \%$ general measures along with conservative management was done and in only $2.27 \%$ general method of treatment was used.

Table-4: Showing the outcome among the study subjects

\begin{tabular}{|l|l|l|}
\hline Treatment outcome & Frequency & Percentage \\
\hline Healed & 33 & 75 \\
\hline Not Healed & 11 & 25 \\
\hline
\end{tabular}

Above table suggests that $75 \%$ i.e., 33 study subjects were observed to be completely healed and the remaining 17 out off 44 study subjects were not healed completely.

Table-5: Showing relationship between the outcome and sociodemographic characteristics

\begin{tabular}{|l|l|l|l|l|}
\hline Characteristics & Healed & Non Healed & P value \\
\hline \multirow{3}{*}{ Gender } & Male & 22 & 8 & 0.709 \\
\cline { 2 - 4 } & Female & 11 & 3 & \\
\hline \multirow{2}{*}{ Occupation } & Employed & 24 & 11 & 0.05 \\
\cline { 2 - 4 } & Unemployed & 9 & 0 & \\
\hline & Literate & 27 & 0 & \multirow{2}{*}{0.001} \\
\cline { 2 - 4 } & Illiterate & 6 & 11 & \\
\hline
\end{tabular}

From the above males consists of $66.67 \%$ of study population where ulcer was healed and $72.73 \%$ where the ulcer was not properly healed. And in females $33.33 \%$ of them healed and $27.27 \%$ were not healed. No statistically significant association was observed treatment method and gender $(\mathrm{P}$ value $>0.05$ ). Coming to the occupation, there was also no significant association found between employment and the outcome $(p=0.05)$. But a statistically significant difference was observed with literacy status and the outcome with a $\mathrm{p}$ value of $<0.001$.

\section{DISCUSSION}

In the current study the outcome in patients with venous ulcer was studied after treatment. The study includes a total of 44 study subjects who attended the out patient department of department of surgery at an tertiary care hospital, Kuppam. The complete data including sociodemographic profile and treatment history were collected with the help of questionnaire and the outcome after treatment was noted. It was observed that major proportion i.e., $68.18 \%$ were males of the patients were males and remaining were females. And $79.54 \%$ of the study subjects belong to $31-60$ years of age group and the remaining $9.1 \%$ and
$11.36 \%$ ) consists of $\leq 30$ years and $>60$ years age group. And there is no statistically significant association found between age group and gender ( $p$ value of $>0.05$ ). From total of 138 study subjects $70.29 \%$ were reported to be females and the remaining $29.71 \%$ were males and most of the patients were over 65 years of age i.e., around $85 \%$ [6]. Skaraborg study reported that $59.1 \%$ were females and $40.9 \%$ comprised of males with a high proportion of study subjects i.e., $82 \%$ falling under the age group of $>64$ years and they also reported that only $46 \%$ of the ulcers were pronouncedly healed [10].

It was reported that $71.3 \%$ of the study subjects were females and remaining $28.7 \%$ were males and $54.8 \%$ of the patients were found to have ulcers on the left limb, $45.3 \%$ of them were affected on the right limb and remaining were having involvement of both limbs among a total of 94 patients with ulcers [7]. But in the present study $59 \%$ of study subjects had ulcers on right limb, in $27.27 \%$ of them only left limb involvement was seen and in the remaining $13.73 \%$ ulcers were found on both the limbs. Pain is common complaint which was observed in all the study subjects. 
In the current study 33 study subjects out of 44 were observed to be completely healed and the remaining 17 study subjects were not healed completely. In the Skaraborg study, after a mean follow-up period of 54 months, $54 \%$ of the venous ulcers were healed, $43 \%$ were open, and $3 \%$ of the legs were amputated [8]. Ninety-one ulcers $(92 \%)$ healed at a median time of 3.4 months and eight ulcers that did not heal during the study period had a median treatment duration of 14.1 months was reported by Curtis et al., [11].

On studying the outcome of treatment of venous ulcers with respect to gender, occupation and literacy status of study subjects it was observed that there is significant association found with healing and gender of the study population, a considerable association was observed with the state of employment with the study subjects who are working under hazardous environmental conditions (dust, smoke polluted areas etc.). But a statistically highly significant association was observed with literacy status and outcome of the treatment, where all the study subjects who were literate had been completely healed and among the illiterates only $35.29 \%$ has been healed. Except for a significantly lower income in the ulcer group, there was a surprising lack of differences in socioeconomic factors, as $74 \%$ of the patients with ulcers earned less than BPL income per year as when compared with patients without ulcers only $50 \%$ of the patients were earning less than BPL income per year [9].

\section{CONCLUSION}

Care for venous ulcers on legs has improved in recent years with various new approaches. Regular clinical evaluations, poor compliance and patient education were independently correlated with poor prognosis for ulcer healing. Other factors such as age, gender etc did not interfere significantly with healing. On the basis of the above stated findings, some measures should be planned to encourage early self referral, to identify and prevent factors associated with poor healing prognosis.

\section{IMPLICATIONS OF THE STUDY}

- There is need for establishment of leg ulcer clinics in the community for better healing

- Availability of new treatments which may help in the improvement in the care of venous ulcers.
Conflict of Interset: None

\section{Financial Support: Nil}

\section{REFERENCES}

1. Moffatt CJ, Franks PJ, Oldroyd M, Bosanquet N, Brown P, Greenhalgh RM, McCollum CN. Community clinics for leg ulcers and impact on healing. BMJ. 1992 Dec 5;305(6866):1389-92.

2. Anning ST. Venous Leg Ulcers. British Medical Journal, November 1966; 1183-1186.

3. Anonymous. The treatment of varicose veins [Editorial]. Lancet, 1975; 2:311-312.

4. Millard LG, Roberts MM, Gatecliffe M. Chronic leg ulcers treated by the pinch graft method. British Journal Dermatol. 1977; 97:289-95.

5. Browse NL. Venous ulceration. British Medical Journal, 1983; 286:292.

6. Tennvall GR, Jonas H, Rut I. The cost of treating hard to healvenous leg ulcers: results from a Swedish survey. SMTL, February 2001.

7. Scotton MF, Miot HA, Abbade LP. Factors that influence healing of chronic venous leg ulcers: a retrospective cohort. Anais brasileiros de dermatologia. 2014 Jun;89(3):414-422.

8. Nelzen O, Bergqvist D, Lindhagen A. Long-term prognosis for patients with chronic leg ulcers: a prospective cohort study. European Journal of Vascular and Endovascular Surgery. 1997 May 1;13(5):500-508.

9. Bergqvist D, Lindholm C, Nelzén O. Chronic leg ulcers: the impact of venous disease. Journal of vascular surgery. 1999 Apr 1;29(4):752-755.

10. Forssgren A, Fransson I, Nelzén O. Leg ulcer point prevalence can be decreased by broad-scale intervention: a follow-up cross-sectional study of a defined geographical population. Acta dermatovenereologica. 2008 May 1;88(3):252-6.

11. Erickson CA, Lanza DJ, Karp DL, Edwards JW, Seabrook GR, Cambria RA, Freischlag JA, Towne JB. Healing of venous ulcers in an ambulatory care program: the roles of chronic venous insufficiency and patient compliance. Journal of vascular surgery. 1995 Nov 1;22(5):629-36.

12. Browse NL and Burnand KG. The cause of venous ulceration. Lancet, 1982;2:243-45.

13. Baker SR, Stacey MC, Jopp-McKay AG, Hoskin SE, Thompson PJ. Epidemiology of chronic venous ulcers. British Journal of Surgery. 1991 Jul;78(7):864-7. 